\title{
THE CHALLENGE OF
}

\section{THE DRUMS}

\section{An address given on conferment of the degree of Honorary Doctor of Literature by Victoria University of Wellington, 16 April 1999}

\author{
ALISTAIR TE ARIKI CAMPBELL
}

\section{I} WANT TO THANK Victoria University for conferring on me this honorary degree of Doctor of Literature It is a great honour and I'm still trying to live with it, to live up to it.

When you honour a Polynesian, you honour the tribe, the island, the race. There will be many people today rejoicing in this honour because it is theirs as well.

The drums have thrown out a challenge for me to pass on to you, especially the Pacific Islanders among you. Build your canoe for the long voyage that awaits you. That's the message of the drums:

Build your canoe build it now.
Make it strong, make it tight.
Nail to the mast the colours of Io,
the Hidden One. Our goal is Savaiki,
so let it be swift, let it be true,
let it sing as it slices the skin of the sea.

My address won't be weighty or profound. It will be more like a chat around a fireplace, giving impressions of life at Weir House and the University in the late 1940s.

It was a cold bleak morning in November 1944 when I stepped off the Lyttelton ferry in Wellington. I remember looking about me and wondering what on earth I was doing in this drab war-time city where I knew no one. Then came news that was to change my life. I had been accepted by Weir House as a boarder. I suddenly found myself in the company of young men who thought about poetry as I did. I soon got to know people like Pat Wilson and Bill Oliver. They may have been students, but they were also good poets whose poems were more sophisticated and accomplished than mine. Over the next three years I learnt a great deal from them.

The University in those days was quite small. All the lectures and the library were able to be squeezed into the building now known as the Hunter. It was affiliated to the University of New Zealand, and had a student roll of about 2,000, many of whom, perhaps a majority, were part-time students. As a result, unkind critics spoke of it as a night school. Night school or not, it was a lively place, intellectually and physically, with a variety of student clubs - sporting, cultural, and political.
The nucleus of the Victoria University College Literary Society was formed at Weir House, comprising Pat Wilson, Bill Oliver, Harry Orsman, Gordon Orr and myself, and we were joined outside the house, by students like Erik Schwimmer, Hubert Witheford, a poet, Elizabeth Entrican, a poet (later married to Gordon Orr, and more recently Chancellor of this University), Neil Mountier and John Mansfield Thomson, our editor.

We were given support and encouragement by Professor Ian Gordon, who, incidentally, suggested the title of our first literary magazine, Hilltop. The society moved down into the city, as its members graduated and left the University, and in time it became known as the Wellington group of writers. It was at this stage that James K. Baxter, Louis Johnson, and Peter Bland, all poets, and our two secretarial assistants, Lorna Clendon, a poet, and Judith Wild joined us.

Harry Orsman is my oldest friend, and I'd like to pay tribute to him for his superb Oxford New Zealand Dictionary. There were 
scoffers who said, 'Harry can't be taken seriously. He's too scurrilous.' They have been proved wrong. Harry is a great New Zealander warts and all.

Erik Schwimmer was Dutch, an impractical intellectual and eccentric, who introduced a cosmopolitan note to our publications with his articles on Camus and Sartre. Erik's personal oddities gave rise to many amusing stories. There was the time, for example, when he was anxious to start his novel, but he wanted somewhere quiet, but not too remote. He chose Naseby. I decided to call on him to see how he was managing. He had rented a small tin hut in the middle of a paddock which he shared with an old grey mare. I knocked on the door. No answer. The door was unlatched, so I pushed it open. All I could see was a pair of spectacles suspended in mid air, reflecting light from a small cobwebby window on the far wall. Then Erik's face came into view, smeared with soot from a pot-bellied stove he'd been trying unsuccessfully to light.

'Ah, Alistair,' he said. 'I'm pleased to see you. I don't like it here. The hut's haunted. At night it shakes, I hear heavy breathing and I can't get to sleep.' I knew at once what the trouble was. 'It's not haunted, Erik. 'It's the old horse rubbing itself against the hut. Horses like a good scratch.' The relief on Erik's face was comical to see. 'A horse,' he said. 'Well, well a horse'. He laughed. Then there was the time he tripped and fell, cutting his backside on broken glass. He placed a mirror on the floor, lowered himself over it so he could see what he was doing, then carefully placed sticking plaster on his wounds. Next morning his wife was surprised to see a mirror on the floor with sticking plaster on it. I don't think Erik was ever aware he acted oddly. He was a loveable human being.

Professor Gordon taught English. He had recently taken up the position, and was a youngish man, full of enthusiasm for his subject that he was able to communicate to his students. He was vain and likeable, and a superb lecturer. Other inspiring teachers were Professors Baillie and Somerset, who taught education.

My first Latin teacher was Professor Rankine Brown, a noted classicist in his day. He was one of the four original professors of this University, having been appointed in 1899, and by 1945 he was pretty ancient. He may have been frail and doddery, but there was nothing wrong with his mind. Now and then he'd come out with a wicked flash of wit that made you sit up and take notice.

Rankine Brown was replaced by Professor H A Murray, a retiring Scot from Aberdeen. He made Latin live for me. You don't realise what an imprecise language English can be until you do a Latin prose. Latin taught me to be more precise, concise, and direct. After classes I sometimes visited Professor Murray in his study, and he would put aside what he was doing and discuss the authors we were studying in Latin III - Virgil, Horace, and Tacitus. These were among the most rewarding of my University experiences.

At the end of 1947, I left Weir
House for good and the University temporarily, having served what I now look back on as a sort of poetic apprenticeship - there were no creative writing courses in those days. I had written little that I was proud of, but my course was set, my canoe launched, and my voyage under way.

I want to end by reading a poem I wrote for my wife Meg on Christmas day. It's called 'Words and Roses':

I never imagined so rare a night would make me dream of roses the gentle rain, the words falling irresistibly as arrows in flight, sometimes singly, sometimes in a shower, far too many for me to catch, and each a flower without match.

In what other life did you wear them so that they smelt of you? We knew each other well, these words and I, having sung of you everywhere under your spell.

I followed them to the source somewhere north of your heart or was it more to the south? It matters only that they came, from whichever direction, still warm from your mouth.

Dear heart, I had forgotten everything I learnt that love disposes, until last night they came again in a dream with the gentle rain, smelling of you and roses.

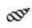

